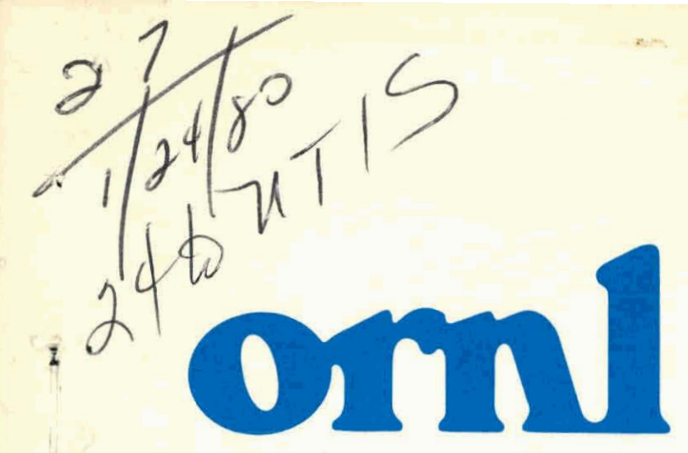

OAK

RIDGE

NATIONAL

LABORATORY

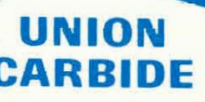

\section{MASTER}

\title{
Nuclear Medicine Technology \\ Progress Report for Quarter Ending September 30, 1979
}

\author{
F. F. Knapp, Jr.
}

OPERATED BY

UNION CARBIDE CORPOBATION

FOR THE UNITED STATES

DEPARTMENT OF ENERGY 


\section{DISCLAIMER}

This report was prepared as an account of work sponsored by an agency of the United States Government. Neither the United States Government nor any agency Thereof, nor any of their employees, makes any warranty, express or implied, or assumes any legal liability or responsibility for the accuracy, completeness, or usefulness of any information, apparatus, product, or process disclosed, or represents that its use would not infringe privately owned rights. Reference herein to any specific commercial product, process, or service by trade name, trademark, manufacturer, or otherwise does not necessarily constitute or imply its endorsement, recommendation, or favoring by the United States Government or any agency thereof. The views and opinions of authors expressed herein do not necessarily state or reflect those of the United States Government or any agency thereof. 


\section{DISCLAIMER}

Portions of this document may be illegible in electronic image products. Images are produced from the best available original document. 


\section{Printed in the United States of America. Available from National Technical Information Service}

U.S. Department of Commerce 5285 Port Royal Road, Springfield, Virginia 22161 NTIS price codes-Printed Copy: A03; Microfiche A01

This report was prepared as an account of work sponsored by an agency of the United States Government. Neither the United States nor any agency thereof, nor any of their employees, makes any warranty, expressed or implied, or assumes any legal liability or responsibility for any third party's use or the results of such use of any information, apparatus, product or process disclosed in this report, or represents that its use by such third party would not infringe privately owned rights. 
Contract No. W-7405-eng-26

Health and Safety Research Division

\section{NUCLEAR MEDICINE TECHNOLOGY PROGRESS REPORT}

\section{FOR QUARTER ENDING SEPTEMBER 30, 1979}

F. F. Knapp, Jr.

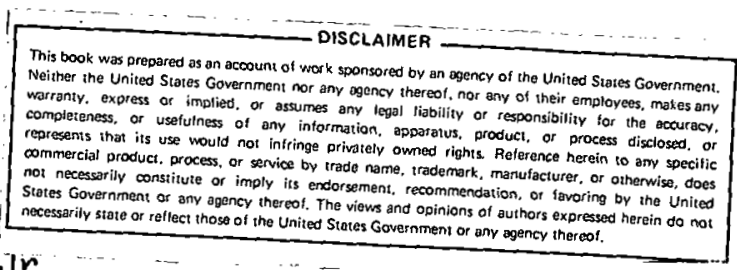

Work sponsored by

DOE Office of Health and

Environmental Research

NOTICE This document contains information of a preliminary nature. It is subject to revision or correction and therefore does not represent a final report.

OAK RIDGE NATIONAL LABORATORY

Oak Ridge, Tennessee 37830

operated by

UNION CARBIDE CORPORATION

for the

DEPARTMENT OF ENERGY 
Previous reports in this series:

ORNL/TM-5809

ORNL/TM-5936

ORNL/TM-6044

ORNL/TM-6181

ORNL/TM-6371

ORNL/TM-6410

ORNL/TM-G638

ORNL/TM-6639

ORNI / TM- 6771

ORNL/TM-6916

ORNL/TM-6958 


\section{CONTENTS}

\section{Page}

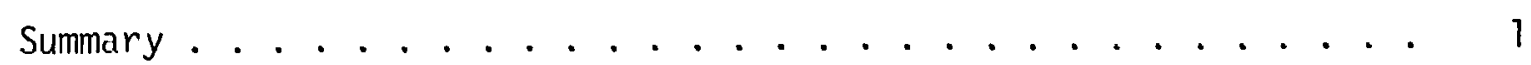

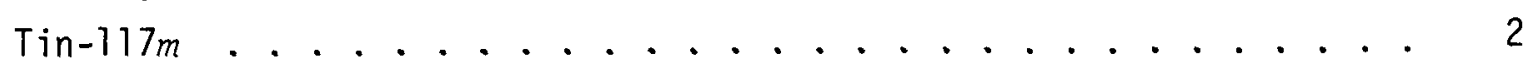

Selenium-75 ...................... 8

Biohazards from Energy Technologies -

An Assay System to Evaluate the

Biological Effects of Arsenic .............. 11

Platinum-195m ...................... 14

Syntheses .......................... 14

Tissue Distribution Studies.............. . . 14

Radionuclides for Medical Cooperative Programs . . . . . . . 19

Carbon-11 ...................... 19

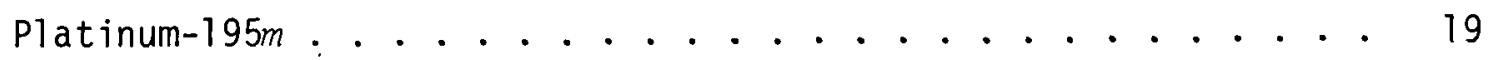

Selenium-75 and Tellurium-123m . . . . . . . . . 20

Other Nuclear Medicine Technology Group Activities . . . . . . 21

Papers and Publications.................. 22

Papers ......................... 22

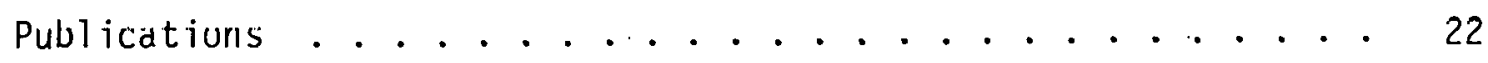

Reports.................. . . 22 
Of special interest in this report is the demonstration of pronounced adrenal uptake in rats of $117 m$ Sn-labeled 23-(trimethyl stanna)-24-nor-5 $\alpha-$ cholan-3B-01. This unusual steroid is an analog of cholesterol in which the side chain terminal isopropyl group has been replaced with the trimethyltin moiety. The adrenal:blood and adrenal:1iver ratios were $33: 1$ and 9:1, respectively, only one day after intravenous administration of the radiolabeled steroid. A variety of $117 \mathrm{~m}$ Sn-labeled steroids with structural modifications of the nucleus and side chain were also prepared to determine the effects of structural modifications on the adrenal uptake of these unusual steroids. The results of tissue distribution studies in rats indicate that the important structural features required for significant adrenal uptake include an all trans ring juncture, an equatorial $\mathrm{C}-3$ hydroxyl group, and a side chain of moderate length.

The diffusion chamber assay system (ORNL/TM-6639, 6771, and 6958) has been assessed as a means of investigating the toxicity and biological fate of trace elements from energy technologies. Diffusion chambers containing a human embryonic lung cell line were implanted in the peritoneal cavities of rats. In a preliminary experiment, the cell population in chambers from rats exposed to $\mathrm{As}_{2} \mathrm{O}_{3}(15 \mathrm{mg} / \mathrm{kg})$ was inhibited $48 \%$ one day after treatment compared to cells from chambers of control animals administered only sal ine.

In this progress report, the results of continuing studies with $/{ }^{3} \mathrm{Se}$, ${ }^{11} \mathrm{C}$, and $195 \mathrm{mpt}-1$ abeled agents are also described. Several ${ }^{75} \mathrm{Se}-1$ abeled long-chain fatty acids were prepared to determine the effects of total chain length and the position of the selenium heteroatom on heart uptake of this potential new class of myocardial imaging agents. Selenium-75labeled 9-selenapentacosanic acid (isosteric chain length $=25$ carbon atoms) showed the highest heart uptake of the compounds investigated. Approximately $1.4 \%$ of the injected dose was detected in the hearts of rats 30 min after injection and the heart:blood ratios were $7: 1$. Preliminary radiation dose estimates have been performed in conjunction with the Oak Ridge Associated Universities (ORAU) for several ${ }^{75} \mathrm{Se}$ and 123 iTe-labeled fatty acids. 
Extrapolation of rat tissue distribution and excretion data for ${ }^{75} \mathrm{Se}-$ labeled 9-selenaheptadecanoic acid and $123 m$ Te-labeled 9-telluraheptadecanoic acid indicate that the human liver would receive the highest absorbed radiation dose (1.4-1.7 rads/mCi).

Tissue distribution studies in rats have now been completed with the following series of $195 \mathrm{mpt}-1$ abeled chloroammine complexes: $\left[\mathrm{Pt}\left(\mathrm{NH}_{3}\right)_{4}\right] \mathrm{Cl}_{2}$, $\left[\mathrm{Pt}\left(\mathrm{NH}_{3}\right)_{3} \mathrm{Cl}\right] \mathrm{Cl},\left[\mathrm{Pt}\left(\mathrm{NH}_{3}\right)_{2} \mathrm{Cl} \mathrm{l}_{2}\right]$ (cis and trans), $\mathrm{K}\left[\mathrm{Pt}\left(\mathrm{NH}_{3}\right) \mathrm{Cl}_{3}\right]$, and $\left[\mathrm{K}_{2} \mathrm{PtCl}_{4}\right]$. The results of these studies have demonstrated that the tissue distribution and excretion characteristics of the chloroammine complexes closely parallel their physicochemical properties. Further patient studies in a Medical Cooperative Program with ORAU have assessed the efficacy of emission computerized tomographic organ imaging with ${ }^{11} \mathrm{C}$-valine, and ${ }^{11} \mathrm{C}$-aminocyclobutanecarboxylic acid (ACBC). In addition, $195 \mathrm{mpt}-1$ abeled cisdichlorodiammineplatinum(II) was supplied to a number of investigators through the Medical Cooperative Programs. Selenium-75 and $123 m_{\mathrm{Te}} \mathrm{T}$ abeled fatty acids were supplied for the first time through a Medical Cooperative Program with the Massachusetts General Hospital and the Harvard Medical School to determine the relative uptake of these new agents in both normal and infarcted heart tissue of rats.

TIN $117 \%$

F. F. Knapp, Jx., T. A. Butler, and K. R. Ambrose

In an earlier report (ORNL/TM-6916), the preparation of a scries of structurally modified steroids containing the trimethyltin moiety in the side chain was described. The synthesis of the $117 m$ Sn-labeled steroids has now been completed, and the results of tissue distribution studies in rats have indicated that important structural features are required for the adrenal uptake of these steroids. The structural modifications that were investigated include alterations of both the steroid nucleus and side chain. The ${ }^{117 m} \mathrm{Sn}$-labeled steroids were prepared by reaction of the $\mathrm{Me}_{3}{ }^{117 m} \mathrm{Sn}-\mathrm{Li}$ reagent with steroid substrates containing a primary bromine in the side chain. The preparation of $\mathrm{Me}_{3}{ }^{117 m} \mathrm{Sn}-\mathrm{L} i$ has been described in detail earlier (ORNL/TM-6639) and is summarized as follows: 


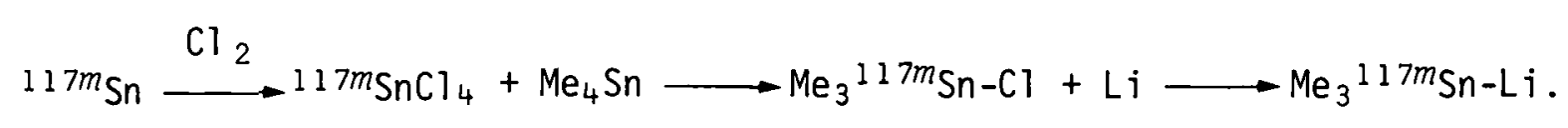

The synthetic procedure has been designed such that all of the reactions are performed in a single reaction vessel, which eliminates losses from solvent extraction, purification of intermediates, and al so reduces the radiation exposure. The steroid substrates and chemical yields of the

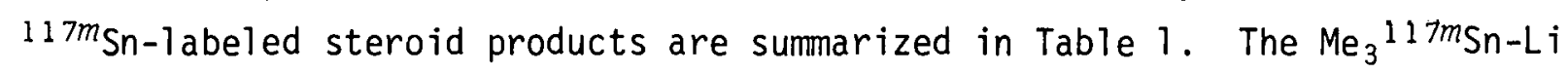
readily reacted with the brominated steroid substrates in tetrahydrofuran at room temperature. Following hydrolysis of the reaction mixtures, the crude products were obtained by solvent extraction and purified by silicic acid column chromatography.

The $117 \mathrm{~m}$ Sn-steroids were administered to rats in an ethanol-tween 80-saline emulsion by injection via a lateral tail vein. Tin-117m-

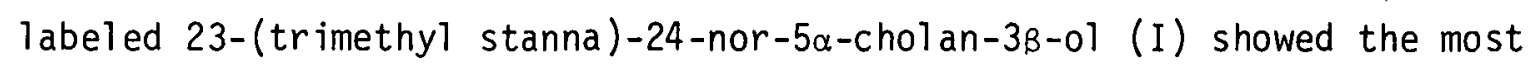
pronounced adrenal uptake of the steroids investigated and the tissue distribution results are shown in Fig. 1. The adrenal uptake was high one day after administration and decreased over the seven day period. After one day, $2.5 \%$ of the administered radioactivity was detected in the adrenal glands; and after seven days, the concentration of radioactivity had been reduced to $1.9 \%$ of the injected dose. These data parallel the results observed with 123mTe-23-(isopropyl telluro)-24-nor-cholan-3B-ol (ORNL/TM5809 ) in which the adrenal accumulation of radioactivity in female rats decreased steadily from $4.5 \%$ of the injected dose after one day to $2.4 \%$ after seven days. A convenient index of the adrenal selectivity of the $117 m_{S n-1}$ abeled steroids is a comparison of either the adrenal:blood or adrenal: liver ratios. The adrenal blood ratios were calculated from the percent dose per gram of tissue values and are compared for the various steroids in Fig. 2. These data dramatically illustrate the effects of steroid structure on the adrenal uptake of the trimethyltin-substituted steroids and indicate that well-defined structural features are required for maximal adrenal uptake. From one analysis of these data it is apparent that an all trans ring juncture, a side chain of moderate length, and an equatorial hydroxyl group are required for adrenal specificity. Similar structure-distribution relationships have been reported earlier for a 


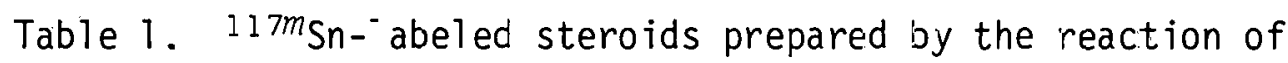
$\mathrm{Me}_{3}{ }^{117 m} \mathrm{Sn}-\mathrm{Li}$ with brominated steroid substraies

\begin{tabular}{|c|c|c|c|}
\hline Substrate & Product & $\begin{array}{c}\text { Unique structural } \\
\text { features }\end{array}$ & $\underset{(\%)}{\operatorname{Yield}^{a}}$ \\
\hline 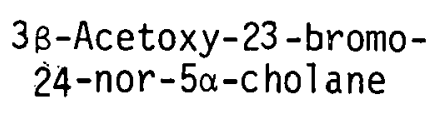 & $\begin{array}{l}23-(\text { Trimethyl stanna) }-24- \\
\text { nor }-5 c-c h o l \text { an }-3 \beta-01 \\
\text { (I) }\end{array}$ & $\begin{array}{l}\text { Saturated nucleus trans ring } \\
\text { structure }\end{array}$ & 49 \\
\hline $\begin{array}{l}\text { 3B-Acetoxy-24-bromo- } \\
\text { chol-5-ene }\end{array}$ & $\begin{array}{l}24-(\text { Trimethyl stanna) - } \\
\text { cha1-5-en-3B-ol (II) }\end{array}$ & Nuclear double bond & 69 \\
\hline $\begin{array}{l}\text { 3B-Methoxy-24-bromo- } \\
\text { chol-5-ene }\end{array}$ & $\begin{array}{l}\text { 3B-Methoxy-24-(trimethyl } \\
\text { stanne)-chol-5-ene (III) }\end{array}$ & Hydrophobic $C-3$ substituent & 34 \\
\hline $\begin{array}{l}\text { 3a-Acetoxy-23-bromo- } \\
24-\text { nor-5B-cholane }\end{array}$ & $\begin{array}{l}23-(\text { Trimethyl stanna) }-24- \\
\text { nor-5E-cholar }-\hat{z} \alpha-01 \text { (IV) }\end{array}$ & Cis A/B ring juncture & 49 \\
\hline 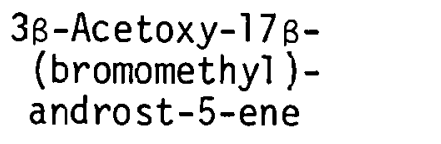 & $\begin{array}{l}\text { 17B-[(Trimethj: }] \text { stanna)methyl }]- \\
\text { androst-5-en-3E-ol }(V)\end{array}$ & Short side chair & 35 \\
\hline
\end{tabular}

${ }^{a}$ Chemical yield values are based upon the brominated steroid starting materials since the $\mathrm{Me}_{3}{ }^{117 m_{\mathrm{Sn}}-\mathrm{Li}}$ reagent was used in considerable excess. 


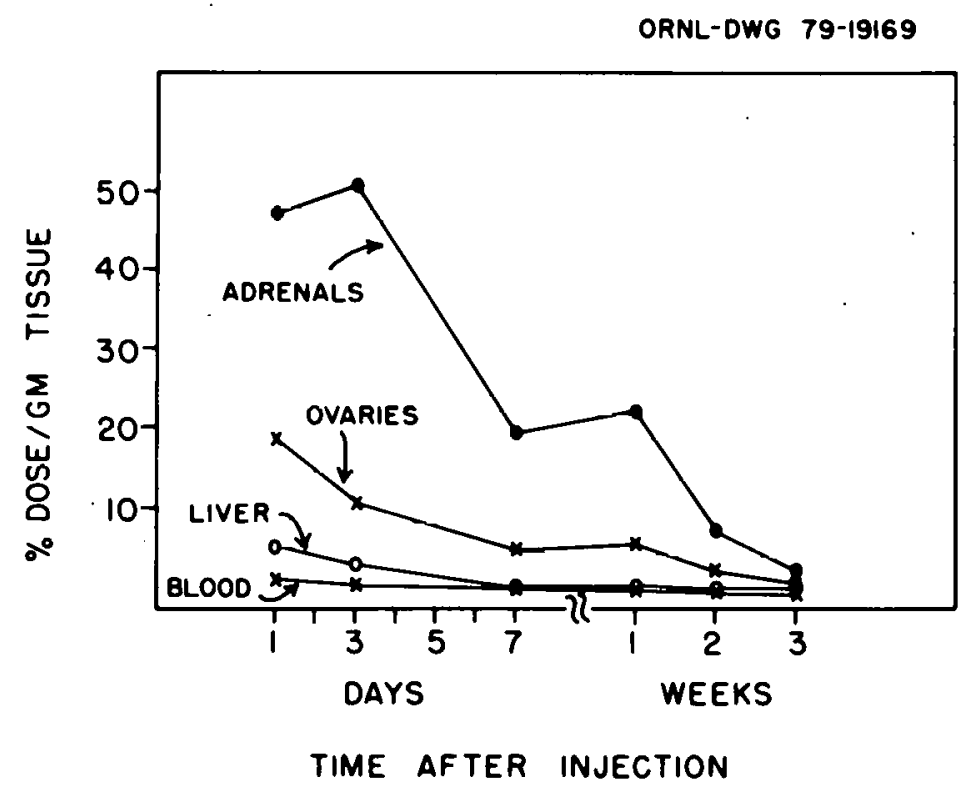

Fig. 1. The distribution of radioactivity in female rat tissues following intravenous administration of $117 \mathrm{mSn}$-1abeled 23-(trimethyl

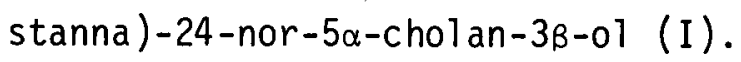

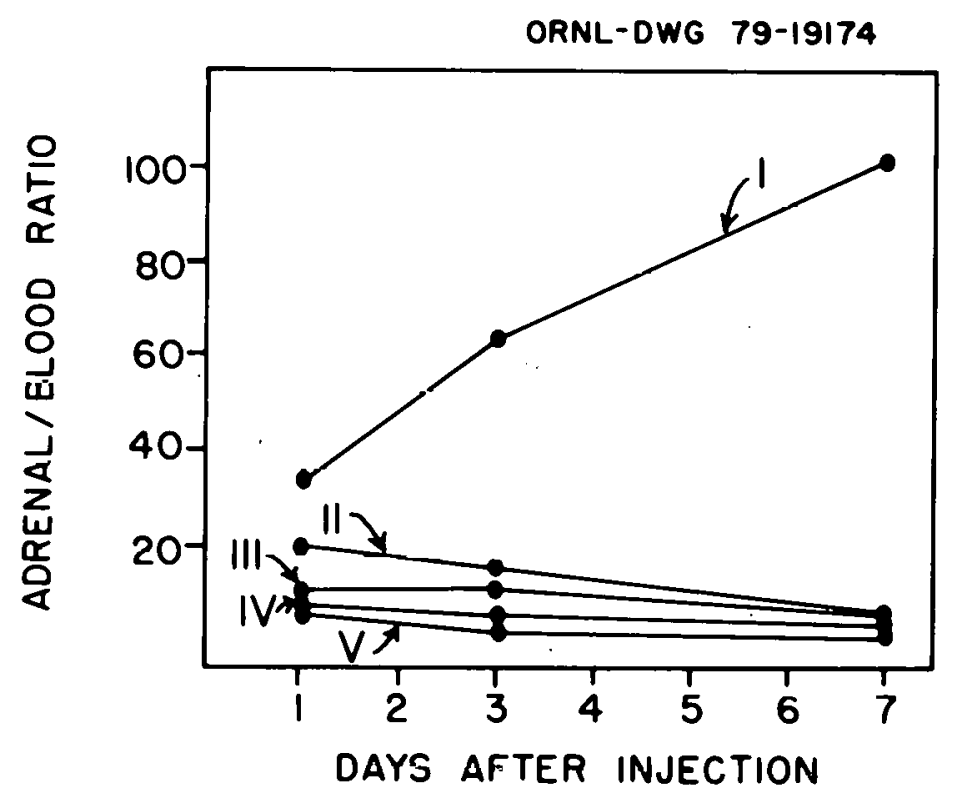

Fig. 2. Comparison of the adrenal:blood ratios at one, three, and seven days following the intravenous administration of $117 \mathrm{~m} S \mathrm{Sn}-1$ abeled steroids (I)-(VI) to female rats. 
series of $123 m_{T e-1}$ abeled steroids (ORNL/TM-6044). An additional interesting observation is the pronounced uptake of radioactivity in the spleen following administration of $117 \mathrm{~m}_{\mathrm{Sn}-1}$ abeled 38-methoxy-24-(trimethyl stanna)chol-5-ene (III) as 117 ustrated in Fig. 3. This unexpected result probably represents sequestration by the spleen of a damaged blood cellular component that tightly binds the $117 \mathrm{~m} \mathrm{Sn}-1$ abeled steroid.

The radioactive contents of the urine and feces of rats were monitored over a seven day period following administration of $117 \mathrm{~m} \mathrm{Sn}-1$ abeled

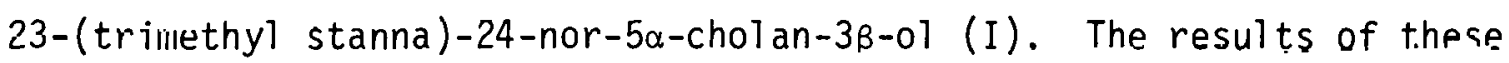
studies (FIg. 4) demonstrate that the majority of the radioactivity was excreted in the feces. Approximately $50 \%$ of the injected radioactivity was excreted within five days. Although the identity of the radioactive contents in the feces has not yet been determined, these data suggest that the trimethyltin moiety remains attached to the steroid molecule since it is well established that neutral steroids are excreted by the fecal route.

The pronounced adrenal uptake in rats indicates that $117 \mathrm{~m} 5 \mathrm{n}-1$ abeled

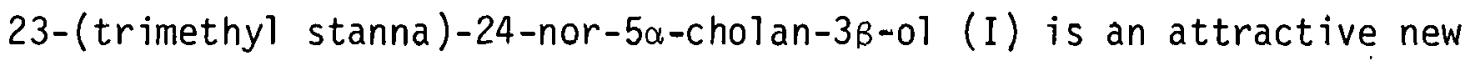
agent for potential adrenal imaging in humans. Future studies with this agent will include attempts to image the adrenal glands of rats, rabbits, and dogs and a more detailed study of the exeretion of radioactivity over a three to four week period. Studies will also be directed at identifying the radioactive species in the feces from rats administered this agent. The potential metabolism of this agent by adrenal glands will be assessed by chromatographic analysis of adrenal extracts following in vivo injection. The radiation dose estimates to human nrgans will al 30 be calculated by extrapolation of the biological data obtained in rats to assess the potenlial usefuiness of $11 / m_{\mathrm{Sn}}-1$ abeled $23-$ (trimethyl stanna) $-24-5 \alpha-$ chulan-3ß-ol (1) for potential adrenal imaging in humans. 


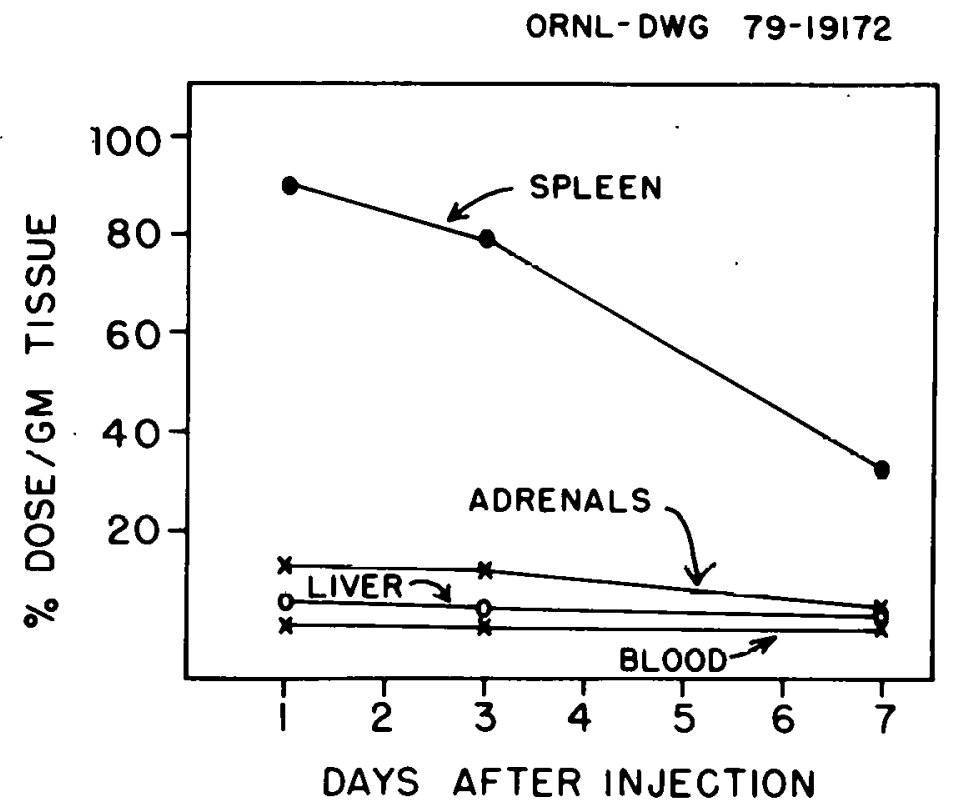

Fig. 3. The distribution of radioactivity in female rat tissues following intravenous administration of $117 m_{\mathrm{Sn}-1}$ abeled $3 \beta$-methoxy-24(trimethyl stanna)-chol-5-ene (III).

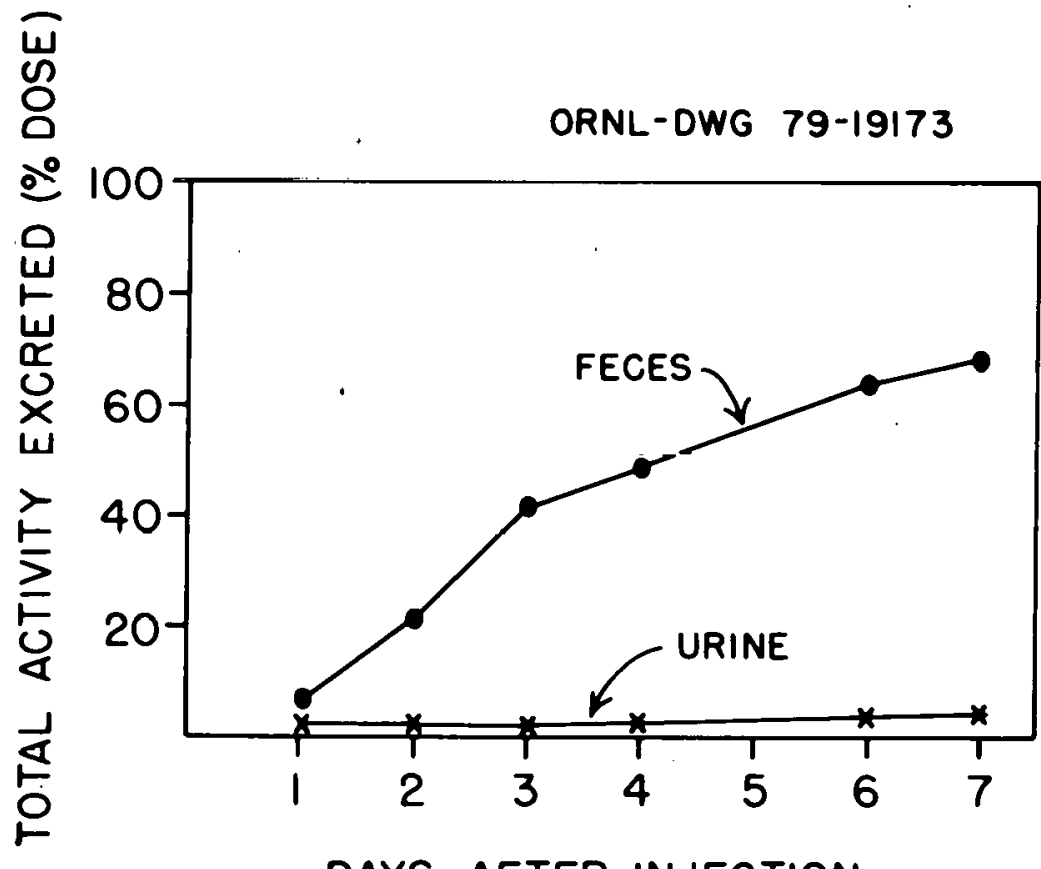

DAYS AFTER INJECTION

Fig. 4. Radioactive contents of feces and urine over a seven day period following intravenous administration of $117 \mathrm{~m} \mathrm{Sn}-1$ abeled 23-(trimethyl

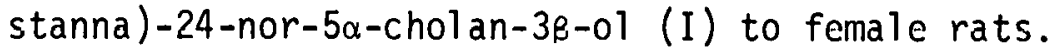




\section{SELENIUM-75}

F. F. Knapp, Jr., K. R. Ambrose, and T. A. Butzer

The significant heart uptake of ${ }^{75} \mathrm{Se}-1$ abeled 9 -selenaheptadecanoic acid was described in an earlier report (ORNL/TM-6916). Although the heart uptake was not as pronounced as that described for the $123 m_{T e-1}$ abeled analog, 9-telluraheptadecanoic acid (ORNL/TM-6638, 6639, 6671, and 6916), the concentration of radioactivity in heart tissue was high enough to indicate that the ${ }^{75} \mathrm{Se}-1$ abeled fatty acid could potentially be used for heart imaging. In addition, the potential use of ${ }^{73} \mathrm{Se}-1$ abeled 9 -selenaheptadecanoic acid for positron emission tomographic studies has been described (ORNL/TM-6958). The heart uptake of a variety of structurally modified ${ }^{75} \mathrm{Se}-\mathrm{l}$ abeled fatty acids has now been investigated to determine the structural features affecting the distribution of these new agents in rats.

The ${ }^{75}$ Se-labeled' fatty acids were prepared by the general method described earlier (ORNL/TM-6638 and 6916) which involves the coupling of alkyl selenols with w-bromo fatty acid methyl esters: $\mathrm{R}-{ }^{75} \mathrm{Se}-\mathrm{H}(\mathrm{Na})+$ $\mathrm{Br}-\mathrm{R}^{1}-\mathrm{COOMe} \longrightarrow \mathrm{R}-{ }^{75} \mathrm{Se}-\mathrm{R}^{1}-\mathrm{COOMe} \longrightarrow \mathrm{R}-{ }^{75} \mathrm{Se}-\mathrm{R}^{1}-\mathrm{COOH}$. The effects of both total chain length and the position of the ${ }^{75}$ Se heteroatom were studied. Selenium-75-labeled methyl-9-selenatridecanoate was prepared by the reaction of 75 Se-butyl selenol with methyl-8-bromooctanoate. This fatty acid has a shorter isosteric chain length (14 carbon atoms) than 9-selenaheptadecanoic acid (18 carbon atoms). Selenium-75-1abeled methyl13-selenaheptadecanoate, an isomer of 9-selenaheptadecanoic acid, was similarly prepared by reaction of ${ }^{75}$ Se-butyl selenol with methy $1-12$ bromododecanoate. A longer chain seleno fatty acid, ${ }^{75}$ Se-methyl-9selenapentacosanate (isosteric chain length $=26$ carbon atoms), was synthesized by reaction of ${ }^{75}$ Se-hexadecyl selennl with methyl-8bromooctanoate.

The ${ }^{75}$ Se-labeled fatty acids were prepared by basic hydrolys is of the methyl esters. After complexing with a $6 \%$ bovine serum albumin solution, the acids were administered to rats by injection via a lateral tail vein. The percent dose per gram of tissue values were determined at 5, 30, and 60 min after injection. These time periods were chosen since earlier 
studies with ${ }^{75} \mathrm{Se}-1$ abeled 9 -selenaheptadecanoic acid had demonstrated that optimal heart uptake was observed within the first hour after injection and the concentration of radioactivity in the heart began to decrease after. one hour. The percent injected dose levels in the heart at 5 and 60 min after injection are compared for the four ${ }^{75} \mathrm{Se}-1$ abeled fatty acids with similar results obtained with $123 \mathrm{mTe}$-1abeled 9 -telluraheptadecanoic acid in Table 2 . The results of the tissue distribution studies with ${ }^{75} \mathrm{Se}-1$ abeled fatty acids demonstrate that heart uptake is effected by total chain length, although not as markedly as reported earlier for a series of $123 m_{T e-}$ 1 labeled fatty acids. The longest chain ${ }^{75} \mathrm{Se}-1$ abeled fatty acid investigated, 9-selenapentacosanic acid, showed heart uptake that was comparable to that reported earlier for $123 m_{T e-1}$ abeled 9-telluraheptadecanoic acid. Five minutes after injection, approximately $1.9 \%$ of the administered radioactivity was detected in the heart and the heart:blood ratio was greater than $7: 1$.

Several experiments were conducted to determine the biological fate of ${ }^{75} \mathrm{Se}-9$-selenaheptadecanoic acid in rats. Examination of the feces and urine of rats over a seven day period indicated a very rapid urinary excretion of radioactivity following administration of this agent (Fig. 5). Approximately $50 \%$ of the administered activity was excreted in the urine within one day. The rapid excretion of radioactivity would suggest that the absorbed radiation dose would not be excessive. Using excretion and tissue distribution data from rats, the radiation doses to humans from ${ }^{75} \mathrm{Se}-9$-selenaheptadecanoic acid and $123 \mathrm{~m}$ Te-9-telluraheptadecanoic acid have been calculated in conjunction with collaborators at the Oak Ridge Associated Universities. The liver receives the highest calculated radiation dose for both agents: ${ }^{75} \mathrm{Se}-9$-selenaheptadecanoic acid, $1.7 \mathrm{rads} / \mathrm{mC}$;

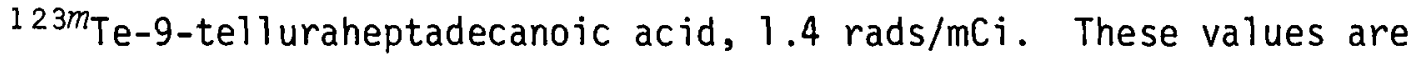
comparable to radiation dose estimates for thallium-201, an agent routinely used for the clinical diagnosis of heart disease.

In order to gain insight into the mechanism of uptake and the fate of ${ }^{75} \mathrm{Se}-1 \mathrm{abel}$ ed fatty acids in heart tissue, it is important to identify the chemical species of the radioactivity in heart tissue following administration of the radiolabeled agent. In a preliminary experiment, rat hearts were homogenized in a chloroform-methanol mixture 30 min following intravenous 
Table 2. Percent injected dose values for the heart and heart:blood ratios determined after administration of ${ }^{75} \mathrm{Se}-1$ abeled fatty acics to female rats. These data are compared with similar values determined earlier for $123 \mathrm{mTe}-1 \mathrm{abel}$ ed

9 -telluraheftadecaroic acid (ORNL/TM-6916)

\begin{tabular}{|c|c|c|c|c|c|c|}
\hline \multirow[b]{2}{*}{ Radiolabeled fatty acid } & \multirow{2}{*}{$\begin{array}{l}\text { Time } \\
(\min )\end{array}$} & \multirow{2}{*}{$\begin{array}{l}\text { Heart uptake } \\
(\%)\end{array}$} & \multicolumn{4}{|c|}{ Calculated heart:tissue ratios ${ }^{a}$} \\
\hline & & & Blood & Liver & Lung & Kidney \\
\hline $\begin{array}{l}\text { 9-Sel enaheptadecanoic acid } \\
\mathrm{H}_{3} \mathrm{C}-\left(\mathrm{CH}_{2}\right)_{7}-\mathrm{Se}-\left(\mathrm{CH}_{2}\right)_{7}-\mathrm{-OOH}\end{array}$ & $\begin{array}{r}5 \\
60\end{array}$ & $\begin{array}{l}0.87 \\
0.68\end{array}$ & $\begin{array}{l}5.38 \\
4.21\end{array}$ & $\begin{array}{l}0.15 \\
0.23\end{array}$ & $\begin{array}{l}1.49 \\
1.32\end{array}$ & $\begin{array}{l}0.81 \\
0.69\end{array}$ \\
\hline $\begin{array}{l}\text { 9-Selenatridecanoic acid } \\
\mathrm{H}_{3} \mathrm{C}-\left(\mathrm{CH}_{2}\right)_{3}-\mathrm{Se}-\left(\mathrm{CH}_{2}\right)_{7}-\mathrm{COOH}\end{array}$ & $\begin{array}{r}5 \\
60\end{array}$ & $\begin{array}{l}0.63 \\
0.27\end{array}$ & $\begin{array}{l}1.93 \\
2.65\end{array}$ & $\begin{array}{l}0.37 \\
0.39\end{array}$ & $\begin{array}{l}1.43 \\
1.39\end{array}$ & $\begin{array}{l}0.74 \\
0.56\end{array}$ \\
\hline $\begin{array}{l}\text { 13-Sel enaheptadecanoic cicid } \\
\mathrm{H}_{3} \mathrm{C}-\left(\mathrm{CH}_{2}\right)_{3}-\mathrm{Se}-\left(\mathrm{CH}_{2}\right)_{11}-\mathrm{C} \mathrm{COH}\end{array}$ & $\begin{array}{r}5 \\
60\end{array}$ & $\begin{array}{l}0.45 \\
0.30\end{array}$ & $\begin{array}{l}3.30 \\
2.82\end{array}$ & $\begin{array}{l}0.12 \\
0.12\end{array}$ & $\begin{array}{l}0.61 \\
0.70\end{array}$ & $\begin{array}{l}0.66 \\
0.53\end{array}$ \\
\hline $\begin{array}{l}\text { 9-Sel enapentacosanic acid } \\
\mathrm{H}_{3} \mathrm{C}-\left(\mathrm{CH}_{2}\right)_{15}-\mathrm{Se}-\left(\mathrm{CH}_{2}\right)_{7}-\mathrm{CCOH}\end{array}$ & $\begin{array}{r}5 \\
60\end{array}$ & $\begin{array}{l}1.9 \\
1.2\end{array}$ & $\begin{array}{r}7.27 \\
10.29\end{array}$ & $\begin{array}{l}0.38 \\
0.30\end{array}$ & $\begin{array}{l}4.77 \\
4.96\end{array}$ & $\begin{array}{l}5.79 \\
3.66\end{array}$ \\
\hline $\begin{array}{l}\text { 9-Tel luraheptadecanoiz acid } \\
\mathrm{H}_{3} \mathrm{C}-\left(\mathrm{CH}_{2}\right)_{7}-\mathrm{Te}-\left(\mathrm{CH}_{2}\right)_{7}-\mathrm{OCH}\end{array}$ & $\begin{array}{r}5 \\
60\end{array}$ & $\begin{array}{r}2.1 \\
1.3\end{array}$ & $\begin{array}{r}10.34 \\
8.87\end{array}$ & $\begin{array}{l}0.53 \\
0.64\end{array}$ & $\begin{array}{l}4.18 \\
6.11\end{array}$ & $\begin{array}{l}2.09 \\
2.74\end{array}$ \\
\hline
\end{tabular}

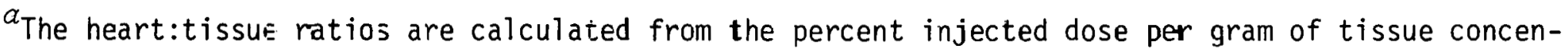
tration values. 
administration of ${ }^{75} \mathrm{Se}-9$-selenaheptadecanoic acid. The organic-soluble material was analyzed by thin-layer radiochromatographic analysis. The results of these studies (Fig. 6) demonstrated that radioactivity co-chromatographed with both the diglyceride and triglyceride standards. Since it is established that long-chain alkanoic acids are stored in the myocardium esterified to glycerol, these data suggest that ${ }^{75} \mathrm{Se}-9-\mathrm{selena}-$ heptadecanoic is metabolized in a similar manner. Future studies will investigate if the ${ }^{75} \mathrm{Se}$-fatty acid is further metabolized by $\beta$-oxidation, the normal route of fatty acid metabol ism.

\section{BIOHAZARDS FROM ENERGY TECHNOLOGIES - AN ASSAY SYSTEM TO EVALUATE THE BIOLOGICAL EFFECTS OF ARSENIC}

\section{K. R. Ambrose}

Arsenic is recognized as a potentially hazardous trace element pollutant of the emerging coal conversion technologies. During coal combustion, arsenic is converted to volatile products; coal liquefaction and gasification processes present additional avenues for potential environmental contamination by arsenic compounds. As an example, arsenic levels can be concentrated as high as twofold in the filter cake and threefold in the char residue of the feed coal in a typical coal liquefaction process. In a coal gasification plant processing 20,000 tons of coal in a day, the amount of arsenic produced daily could theoretically be $800 \mathrm{lb}$ present in gas, $1.51 \mathrm{~b}$ in ash, $0.71 \mathrm{~b}^{\prime}$ in $\operatorname{tar}$ and $0.5 \mathrm{lb}$ in the condensate. As a result of the potential release of large amounts of arsenic to the environment, it is important to investigate the biological effects of arsenic.

The diffusion chamber assay system described in previous reports (ORNL/TM-6639, 6771, and 6958) is a method that can be used to investigate the interaction of radiolabeled pollutants with target cells within an in vivo environment. Under these conditions, both the metabolism of the pollutant and the excretion of the native or metabolized pollutant are possible. The potential toxicity, mutagenicity, and carcinogenicity of arsenic compounds can be studied by analyzing target cells from diffusion chambers implanted within the peritoneal cavities or rats that have been 


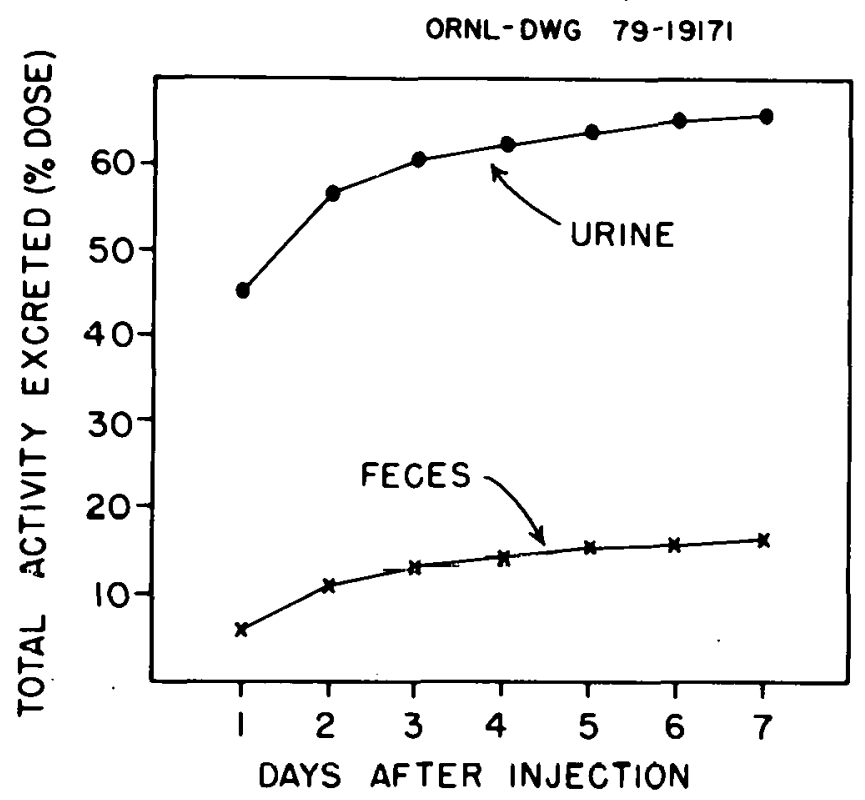

Fig. 5. Radioactive contents of feces and urine over a seven day period following intravenous administration of ${ }^{75} \mathrm{Se}-1$ abeled 9 -selenaheptadecanoic acid to female rats.

ORNL-DWG 79-19170

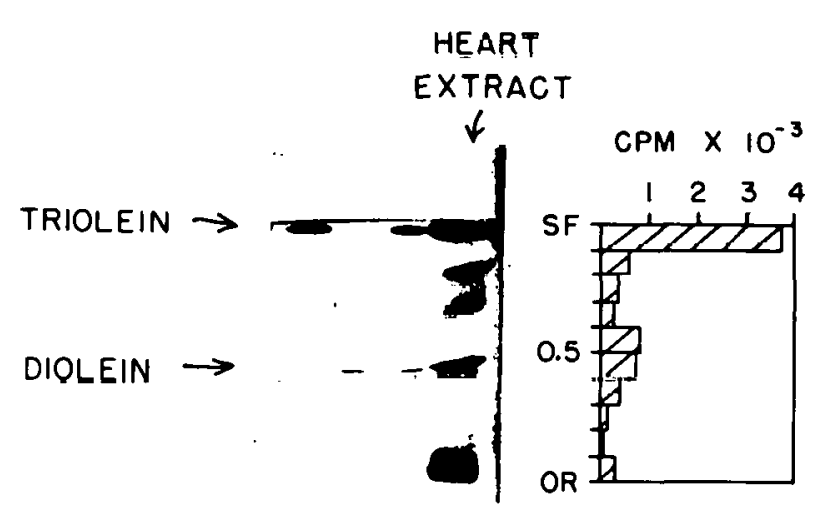

Solvent: Petroleum Ether-Ether-Acetic Acid, 70:30:1

Fig. 6. Thin-layer radiochromatographic analysis of the chloroformsoluble extract of female rat hearts obtained 30 min after intravenous administration of ${ }^{75} \mathrm{Se}-1$ abel ed 9 -selenaheptadecanoic acid. 
exposed to various arsenic compounds. Toxicity is assessed by comparing populations of the arsenic-exposed target cells to control, sal ine-treated populations. After exposure to arsenic in vivo the target cells can be tested for proliferation in soft agar in vitro as an index of the potential carcinogenicity of arsenic. An in vivo modification of the sister chromatid exchange assay can be use to assess the potential mutagenicity of the test compounds.

A human embryonic lung cell line (Flow 2000) has been chosen as a model target cell for the arsenic studies. Preliminary studies during this quarter have involved defining the optimal growth and assay conditions for Flow 2000 cells grown within diffusion chambers implanted in the peritoneal cavities of rats. In contrast to the KB tumor cells used in previous studies, the Flow 2000 cells require a higher seeding level in the chambers $\left(5.0 \times 10^{4}\right.$ vs $\left.2.5 \times 10^{4}\right)$ and have a slower doubling time $(24 \mathrm{hr} v \mathrm{~s} 12 \mathrm{hr}$ ). The Flow 2000 cells also require the use of calciumand magnesium-free media to prevent cell clumping, which can result in an inaccurate estimation of the cell population.

Following the baseline studies, an experiment was performed to determine whether an aqueous solution of arsenic trioxide $\left(\mathrm{As}_{2} \mathrm{O}_{3}\right)$ fed to chamber-containing rats would affect the growth of Flow 2000 cells within the chambers. When the target cell population from arsenic-treated rats was compared to the cell population from the saline-treated control animals, an inhibition of cell division was observed one day after treatment with $\mathrm{As}_{2} \mathrm{O}_{3}$. Growth inhibition was greatest (48\%) in those animals receiving $15 \mathrm{mg}$ of $\mathrm{As}_{2} \mathrm{O}_{3}$ per kilogram of body weight and lowest (18\%) in animals receiving the $5 \mathrm{mg} / \mathrm{kg}$ dose level. Between the first and second day post-feeding, target cells in chambers of all treatment groups (arsenic and control) underwent one doubling in accord with the previously determined doubling time. These preliminary data indicate that the arsenic feeding results in a temporary growth inhibition of human lung cells within the first 24-hr period.

Studies during the next quarter will employ ${ }^{76} \mathrm{As}-1$ abeled $\mathrm{As}_{2} \mathrm{O}_{3}$ to determine the appearance and disappearance of arsenic in the chamber fluid and the uptake of arsenic by the target cells in the chambers. The effect 
of low-1evel chronic exposure to $\mathrm{As}_{2} \mathrm{O}_{3}$ on target cell growth will also be investigated. In addition to these studies, hamsters will be evaluated as chamber recipients for the arsenic studies since the unique binding of arsenic to rat hemoglobin would indicate that experimental data from rats should not be extrapolated to man and other mammals.

\section{PLATINUM- $195 m$}

J. D. Hoeschele and T. A. Butter

An earlier report (ORNL/TM-6371) described the prel iminary tissue distribution data in rats for a series of $195 \mathrm{mpt}-1$ abeled-chloroammineplatinum(II) complexes. Tissue distribution studies with this important series of model complexes have been completed, and a summary of the findings is described below.

\section{Synthesès}

The $195 \mathrm{mpt}$-labeled chloroammineplatinum(II) complexes were prepared by the general reaction scheme (Fig. 7) previously reported (ORNL/TM-6371). In the present studies, the preparation of $K\left[\mathrm{PtACl}_{3}\right]$ and $\left[\mathrm{PtA}_{3} \mathrm{Cl}\right] \mathrm{Cl}$ have been improved $\left(A=\mathrm{NH}_{3}\right)$. The amount of catalyst cmployed in the synthesis of $\mathrm{K}\left[\mathrm{PtACl}_{3}\right]$ is now specified at $5 \%(\mathrm{~W} / \mathrm{W})$. In addition, two al ternate synthetic routes have been evaluated for the preparation of the triammine analog, $\left[\mathrm{PtA}_{3} \mathrm{Cl}\right] \mathrm{Cl}$. The first route is preferred and employs transdichlorodiammineplatinum (trans-DDP) as the starting material while $\left[\mathrm{PtA}_{3} \mathrm{Cl}\right] \mathrm{Cl}$ is prepared in the second route from cis-DDP. This scheme emphasizes the central and important role that cis-DDP has served in the development of microscale syntheses of the chloroammineplatinum(II) analogs.

\section{Tissue Distribution Studies}

Several observations have been made by a comparison of the distribution and retention of radioactivity in 14 tissues $24 \mathrm{hr}$ after administration of the $195 \mathrm{~m} \mathrm{Pt}-\mathrm{labeled}$ chlorammine complexes to female rats. Platinum was found in all of the tissues examined for the various compounds 


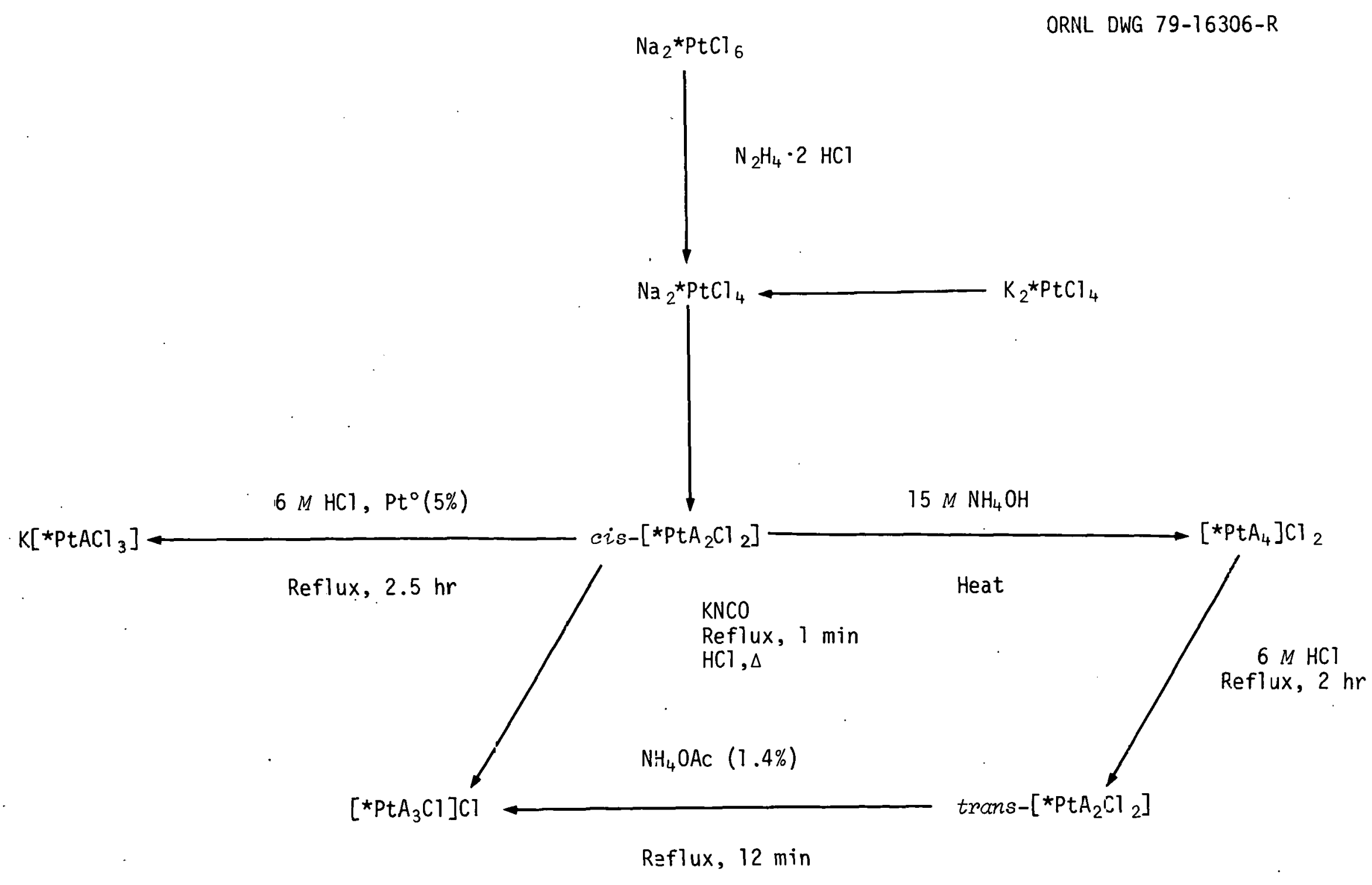

Fig. 7. The s.ynthesis of $195 \mathrm{mpt}-1$ abeled chloroammineplatinum(II) complexes. $\left(A=\mathrm{NH}_{3},{ }^{*}=195 \mathrm{mPt}\right)$. 
and the highest levels were found in kidney $(0.2-4 \%)$. In general, the lowest levels were detected in the brain $(0.01-0.05 \%)$. Although compound retention patterns are unique, uptake is not sufficiently high (with the exception of the kidney) nor selective enough in any given tissue to warrant consideration of any of these compounds as potential imaging agents. The average relative order of decreasing tissue levels (percent dose per gram of tissue) for the $195 \mathrm{mpt}$-labeled complexes in female rats is as follows: kidney > liver > lungs > genitals > spleen > blood > bladder > adrenals > colon > heart > pancreas > small intestine > skin > stomach > brain, while that for cis-DDP alone is: kidney > genitals > liver > adrenals $>$ spleen $>$ blood $>$ lungs $>$ pancreas $>$ heart $>$ brain. The rat ovary exhibited the second highest uptake of radioactivity following administration of $195 \mathrm{mpt-cis-DDP}$, and malignancies of these same tissues in humans respond well to cis-DDP chemotherapy. This association, however, does not imply that high tissue uptake necessarily predicts chemotherapeutic effectiveness for tumors of the same tissue origin. Tumors of the liver and particularly the kidney are of relatively low incidence, and these tissues are generally sites of relatively high uptake. This association could be more than just a mere coincidence. Another important empirical observation is that compound levels in tissues generally increase in the order:

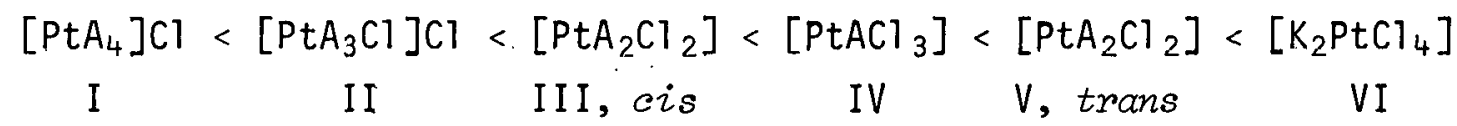

It is significant that the general order of compound retention parallels trends both in the negative charge on the complex and the number of replaceable chloride ligands which is equivalent to the number of binding sites on the central atom, Pt(II). It is also apparent that the complexes which are retained to the greatest extent (IV, V, VI) contain more reactive chlorides by virture of the trans-activating effect of mutually opposed chloride ligands. Also, the order of compound retention in the tissues more closely follows the trend in rate constants, $k_{1}$, rather than equilibrium constants, $\mathrm{K}_{\mathrm{eq}}$, for the first step of the aquation process. The aquation process is likely to be an important first step in the in vivo reactions of platinum(II) complexes in general and can be represented in the following way using cis-DDP as an example: 


$$
\operatorname{cis}-\left[\mathrm{Pt}\left(\mathrm{NH}_{3}\right)_{2} \mathrm{Cl}_{2}\right]+\mathrm{H}_{2} \mathrm{O} \underset{\mathrm{k}_{2}}{\stackrel{\mathrm{k}_{1}}{\rightleftharpoons}} \operatorname{cis}-\left[\mathrm{Pt}\left(\mathrm{NH}_{3}\right)_{2} \mathrm{Cl}\left(\mathrm{H}_{2} \mathrm{O}\right)\right]^{+}+\mathrm{Cl}^{-} \text {, }
$$

where $k_{1}$ and $k_{2}$ are first order rate constants $\left(\mathrm{sec}^{-1}\right)$ for the forward step (aquation) and reverse step (anation), respectively, and the equilibrium constant is numerically equal to the ratio of $k_{1}$ and $k_{2}$ ( $i . e ., k_{e q}=$ $\left.k_{1}: k_{2}\right)$. The parallel in the general order of compound retention in the tissues with trends in $k_{1}$ and $k_{e q}$ values is illustrated in Fig. 8, using retention in the kidney as a typical example of tissue retention. The values of $k_{1}, k_{e q}$, and the average levels found in the kidney have been normalized relative to those for cis-DDP. Comparison of these data shows closer agreement between trends in organ retention and rate constants rather than equilibrium constants. If compound retention in the kidney paralleled $K_{e q}$ values more closely than $k_{1}$ values, a substantially lower level of retention in the kidneys would have been anticipated for transDDP. These results suggest that kinetic factors, as might have been

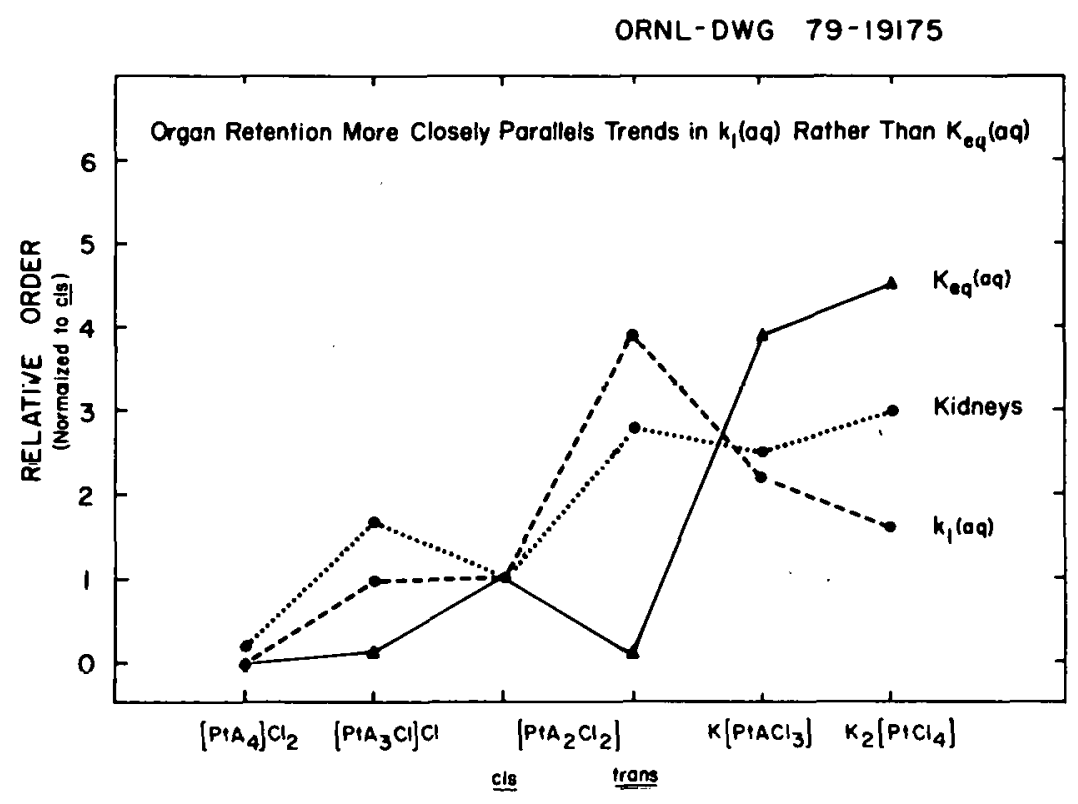

Fig. 8. Comparison of the relative order of kidney retention of $195 \mathrm{mpt}-\mathrm{labeled}$ chloroammineplatinum(II) complexes with the rate constants $\left(k_{1}\right)$ and equilibrium constants $\left(k_{e q}\right)$ for the aquation process. 
predicted a priori, play a dominant role in the binding/retention and potential activity/toxicity of these complexes in vivo. The average order of compound retention in normal tissues does not parallel trends in the antitumor potential of these compounds. For example, complexes $V$ and VI exhibit the highest tissue levels but show virtually no antitumor activity, and complex IV exhibits only marginal antitumor activity but is retained to a greater extent than cis-DDP, the most potent antitumor active Pt(II) complex. Certainly uptake is a necessary, but not a sufficient criterion of antitumor activity; and other criteria, such as the nature and type of binding at the target site, are far more important than uptake in el iciting antitumor activity.

Trends in the distribution coefficients, $K_{d}$, between $n$-octanol/sal ine and the biological half-life data, $T_{1 / 2}$, determined from cumulative urine and fecal excretion of $195 \mathrm{mpt}$ activity are consistent with the order of compound retention. The distribution coefficient for $\mathrm{K}_{2} \mathrm{PtCl}_{4}$ (VI) has not been determined. The $K_{d}$ values are highest for trans-DDP, a neutral and non-polar analog. Adequate data are not available at the present time to evaluate the $T_{1 / 2}$ for trans-DDP.

The relationship between tissue distribution and kinetic lability of chloroammineplatinum(II) complexes gives credence to the "Concept of the Window of Lability." Although generally applied to isostructural complexes of the same net charge, this principle is of general applicability and can be applied to the series of chloroammineplatinum(II) complexes that have been investigated. According to this concept, complexes which are chemically too inert will be too unreactive and will either not reach the target site or will not react with the target site at a sufficient rate or to a sufficient extent to elicit the critical biological response. Such inert. compounds are anticipated to exhibit a short $T_{1 / 2}$, have relatively low retention in the body as well as be relatively non-toxic. On the other extreme, complexes which are chemically too reactive will be indiscriminate in their binding and will be scavenged by a host of biologically important molecules. These complexes are expected to be less active biologically, exhibit a relatively long $T_{1 / 2}$, have a high tissue retention, and be relatively toxic. Between the extremes of too inert and too reactive lies a region of optimal lability within which one would expect to find 
complexes of optimal biological activity. The data for trans-DDP compared to $\left[\mathrm{Pt}\left(\mathrm{NH}_{3}\right)_{4}\right] \mathrm{Cl}_{2}$ illustrate that this concept can be validly applied to the chloroammineplatinum(II) complexes since these two complexes lie near the extremes of reactivity and toxicity and are virtually devoid of antitumor activity.

RADIONUCLIDES FOR MEDICAL COOPERATIVE PROGRAMS

F. F. Knapp, Jr., J. D. Hoeschele, and $T$. A. Butler

Carbon-11

Five ${ }^{11} \mathrm{C}$ production runs were made for the Medical Cooperative Program with Oak Ridge Associated Universities (ORAU) to study the application of ${ }^{11} \mathrm{C}-\mathrm{labeled}$ amino acids for tumor localization and pancreas imaging in human patients. Eight batches of ${ }^{11} \mathrm{C}$-DL-tryptophan and three batches of ${ }^{11} \mathrm{C}-\mathrm{DL}$-valine were prepared and tested in patients at the ORAU Medical Division for tomographic visualization studies of various types of pancreatic disorders. Five batches of ${ }^{11} \mathrm{C}$-labeled 1 -aminocyclobutane carboxylic acid ( $\left.{ }^{11} C-A C B C\right)$ were prepared and studied similarly for visualization of a variety of solid tumors. A total of 14 patients were examined with the ${ }^{11} \mathrm{C}-\mathrm{l}$ abeled amino acids. Two preparations of ${ }^{11} \mathrm{C}-\mathrm{label}$ ed phenethylamine were utilized in preclinical studies to determine its potential application for brain function studies. The latter study includes the University of Kentucky as well as ORAU in the cooperative program.

\section{Platinum- $195 m$}

Collaborators in the Medical Cooperative Program investigating platinum antitumor agents were supplied with $195 \mathrm{mpt}-1$ abeled compounds. Two shipments of $\mathrm{Na}_{2} \mathrm{PtCl}_{6}$ were supplied to the University of Kentucky Medical School (Dr. P. DeSimone). One shipment of cis-dichlorodiammineplatinum(II) (cis-DDP) was al so supplied to this institution for further studies of nephrotoxicity and protein binding of platinum compounds. One shipment of cis-DDP was supplied to the Radiopharmacy Department at the University of Southern Cal ifornia (Dr. W. Wolf) for radiopharmacokinetic studies. One shipment of cis-DDP was supplied to the Medical School at 
the University of California at Los Angeles (Dr. E. Petrilli) for preclinical nephrotoxicity studies in dogs in anticipation that the agent will be utilized in future clinical investigations.

\section{Selenium-75 and Tellurium-123m}

A new Medical Cooperative Program was established with the Nuclear Medicine Division of Massachusetts General Hospital (Dr. H. William Strauss) to amplify and extend the preclinical studies of a unique class of radiolabeled selenium and tellurium fatty acids as potential myocardialimaging agents. The program was initiated by supplying ${ }^{75}$ Se-methyl-9selenaheptadecanoate and $123 m$ Te-methyl-9-telluraheptadecanoate. The heart uptake of these agents will be determined in normal rats and in rats that have myocardial infarctions induced by ligation of a coronary artery to determine if the fatty acids show specific uptake in normal heart tissue compared to the diseased tissue. The success of these preliminary studies will indicate if future imaging studies of infarcted dog hearts will be attempted. 
OTHER NUCLEAR MEDICINE TECHNOLOGY GROUP ACTIVITIES

Potassium- 43 was supplied to several institutions on a cost recovery basis. Five shipments of ${ }^{43} \mathrm{~K}$ were made to the National Institute for Environmental Health Studies. Three shipments were made to the National Institutes of Health, Bethesda, Maryland, and also three shipments to the University of Mississippi Medical Center. One shipment was supplied to the University of Connecticut Medical School.

F. F. Knapp, Jr. participated in the Third International Symposium on the Chemistry of Organo Selenium and Tellurium Compounds at Metz, France, on July 9-12, and attended the Twenty-sixth Annual Meeting of the Society of Nuclear Medicine at Atlanta, Georgia, June 26-29, 1979. J. D. Hoeschele participated in the Symposium on Inorganic Chemistry in Biology and Medicine held as part of the Annual Meeting of the American Chemical Society at Washington, D. C., on September 9-14. 


\section{PAPERS AND PUBLICATIONS}

\section{Papers}

J. D. Hoeschele and T. A. Butler, "Correlations of Physico-Chemical and Biological Properties with In Vivo Biodistribution Data for Pt-195mLabeled Chloroammineplatinum(II) Complexes, "American Chemical Society Meeting, Washington, D. C., September 9-14, 1979.

F. F. Knapp, Jr., "Tellurium-123m-Labeled Radiopharmaceuticals," Third International Symposium on Organo Selenium and Tellurium Compounds. Metz, France, July 9-12, 19\%.

\section{Publ ications}

J. H. Coggin and K. R. Ambrose, "Embryonic and Fetal Determinants on Virally and Chemically Induced Tumors, "Methods in Concer Research, Vol. XVIII, Oncodevelopmental Antigens, pp. 371-389, W. H. Fishman and H. Busch, eds., Academic Press, N. Y., 1979.

F. F. Knapp, Jr., "The Mass Spectral Fragmentation of Phenyl w-Dialkoxyethyl Tellurides," Org. Mass Spectrom. 14, 341, 1979.

\section{Repurts}

F. F. Knapp, Jr., Nuclear Medicine Tecinology Progress Report for Quarter Ending March 31, 1979, ORNL/TM-6916.

F. F. Knapp, Jr., Nuclear Medicine Technology Progress Report for Quarter Ending June 30, 1979, ORNL/TM-6958. 
ORNL/TM-7072

\title{
INTERNAL DISTRIBUTION
}

\author{
1. K. R. Ambrose \\ 2. S. I. Auerbach \\ 3. J. A. Auxier \\ 4. J. M. Becker \\ 5. T. A. Butler \\ 6. A. P. Callahan \\ 7. J.A. Cox \\ 8. K. F. Eckerman \\ 9. L. A. Ferren \\ 10. R. B. Gammage \\ 11. A. S. Garrett, Jr. \\ 12. W. R. Garrett \\ 13. C. E. Guyer \\ 14. J. D. Hoeschele \\ 15. S. V. Kaye \\ 16-20. F. F. Knapp, Jr. \\ 21. E. Lamb \\ 22. B. F. Maskewitz
}

23.

24 .

25.

26 .

27.

28.

29 .

30.

31 .

32 .

33.

34.

35 .

36-37.

38 .

39-40.

41 .

42 .
C. H. Nowl in
C. L. Ottinger
D. C. Parzyck
H. Postma
M. E. Ramsey
C. R. Richmond
J. A. Roberts
A. F. Rupp (Consultant)
C. D. Scott
W. D. Shults
M. R. Skidmore
P. J. Walsh
H. A. Wright
Central Research Library
Document Reference Section
Laboratory Records Department
Laboratory Records, ORNL RC
ORNL Patent Section

\section{EXTERNAL DISTRIBUTION}

43. S. J. Adelstein, M.D., Shields Warren Radiation Lab., Boston, MA 02115

44. H. L. Atkins, M.D., Radiology Dept., State Univ. of New York, Stony Brook, NY 11794

45. J. R. Blair, M.D., DOE-OHER, Washington, DC 20545

46. A. B. Brill, M.D., Medical Dept., BNL, Upton, NY 11973

47. T. F. Budinger, M.D., Donner Lab., LBL, Berkeley, CA 94720

48. R. 1. C.l nutier, MERT, ORAll, nak Ridge, TN 37830

49. M. A. Davis, Shields Warren Radiation Lab., Boston, MA 02115

50. P. A. DeSimone, M.D., V.A. Hospital, Lexington, KY 40507

51. D. R. Hamilton, Nuclear Medicine Branch, FDA, Rockville, MD 20857

52. P. Harper, M.D., Frankl in McLean Memorial Research Institute, Chicago, IL 60637

53. R. L. Hayes, ORAU, Oak Ridge, TN 37830

54. J. Hollifield, M.D., Vanderbilt Univ. Hospital, Nashville, TN

55. K. J. Irgolic, Chemistry Dept., Texas A\&M Univ., College Station, TX 77840

56. D. E. Kuh1, M.D., UCLA, Lab. of Nuclear Medicine, Los Angeles, CA 90024

57. J. S. Laughl in, Sloan-Kettering Inst. for Cancer Research, New York, NY 10021

58. C. C. Lushbaugh, ORAU, Oak Ridge, TN 37830

59. J. N. Maddox, DOE-OHER, Washington, DC 20545 
60. Office of Assistant Manager, Energy Research and Development DOE-ORO, Oak Ridge, TN 37830

61. H. A. O'Brien, LASL, Los Alamos, NM 87545

62. J.K. Poggenburg, Medical Products Division, UCC, Tuxedo, NY 10987

63. P. Richards, BNL, Upton, NY 11973

64. A. Solomon, M.D., UT MRCH, Knoxvil1e, TN 37920

65. H.W. Strauss, M.D., Nuclear Medicine Div., Massachusetts General Hospital, Boston, MA 02114

66-92. Technical Information Center, DOE, Oak Ridge, TN 37830

93. J. Venditti, National Cancer Institute, Silver Spring, MD 20910

94. H. E. Walburg, CARL, Oak Ridge, TN 37830

95. A. P. Wolf, BNL, Upton, NY I I973

96. W. Wolf, University of Southern California, Los Angeles, CA 90033

97. H. R. Wolfe, M.D., DOE-OHER, Washington, DC 20545

98. R. W. Wood, Jr., DOE-OHER, Washington, DC 20545 